\title{
sciendo
}

\section{CONCENTRATION OF BIOACTIVE COMPONENTS IN THE MILK OF SIMMENTAL COWS DEPENDING ON THE FEEDING SYSTEM*}

\author{
Iwona Radkowska ${ }^{1 *}$, Eugeniusz Herbut ${ }^{2}$, Adam Radkowski ${ }^{3}$ \\ ${ }^{1}$ Department of Cattle Breeding, National Research Institute of Animal Production, \\ 32-083 Balice n. Kraków, Poland \\ ${ }^{2}$ Department of Poultry Breeding, National Research Institute of Animal Production, \\ 32-083 Balice n. Kraków, Poland \\ ${ }^{3}$ Department of Grassland Management, Institute of Plant Production, \\ University of Agriculture in Krakow, Al. Mickiewicza 21, 31-120 Kraków, Poland \\ •Corresponding author: iwona.radkowska@izoo.krakow.pl
}

\begin{abstract}
The aim of the study was to determine the yield and chemical composition of milk from TMR(group I) and pasture-fed Simmental cows (group II). The study was conducted with second and third lactation Simmental cows between 30 and 200 days of lactation. The present research showed that compared to TMR feeding, the use of summer pasture feeding and proper supplementation with high-energy feeds allow for higher milk yield and higher nutritive value of the milk. Compared to TMR-fed cows (group I), milk from pastured cows (group II) was characterized by a more beneficial composition of protein fractions, and a higher content of $\alpha$-lactalbumin, $\beta$-lactoglobulin and lactoferrin. It also contained more vitamins $A$ and $\mathbf{E}$, calcium, magnesium and iodine, and had a significantly $(\mathrm{P} \leq \mathbf{0 . 0 5})$ lower cholesterol content. The milk of cows from group II contained over twice as much CLA (1.59\% of all acids) and $35 \%$ more $n-3$ PUFA, which resulted in a more beneficial $n-6 / n-3$ fatty acids ratio of 2.88 . In addition, this milk contained significantly $(\mathrm{P} \leq 0.05)$ less saturated fatty acids (SFA) and significantly more $(\mathrm{P} \leq \mathbf{0 . 0 5})$ mono- (MUFA) and polyunsaturated fatty acids (PUFA). Consequently, the MUFA:SFA and PUFA:SFA ratios in this group were more favourable at $\mathbf{0 . 4 4 8}$ and $\mathbf{0 . 0 6 6}$, respectively. Also the content of desirable fatty acids (DFA) with hypocholesterolemic effects was higher in group II, which resulted in a more beneficial DFA:OFA ratio of 0.8 in this group. In conclusion, the use of summer pasture feeding and a proper supplemented feeding ration in Simmental cows with high-energy feeds allow for high milk yield and high nutritive value of the milk.
\end{abstract}

Key words: cows, milk, feeding, bioactive components

Production efficiency in cows and the composition of their milk are influenced by many factors, including the housing system and feeding method. The majority of cows raised in Poland are fed total mixed rations (TMR). However, due to the growing consumer interest in the quality of food products and also in the way animals are

*This research was funded by statutory activity no. 01-12-04-11 
housed and fed, there is currently an increasing interest in pasture feeding of cows. The conventional management system in which cows are pastured in summer and receive farm-produced feedstuffs in winter can provide opportunities for small farms with adequate grassland (Barłowska et al., 2012), which keep less demanding dairy breeds, such as the Simmental. Due to its nutritional characteristics, milk can be considered a multifunctional food product. It is a source of proteins, lipids, vitamins and minerals as well as biologically active substances which have multidirectional effects on the human body (Kuczyńska et al., 2011). Bioactive milk components (immunoglobulins, hormones, cytokinins, polyamides, enzymes, nucleotides, monoand polyunsaturated fatty acids, fat-soluble vitamins, carotenoids, phospholipids) (Severin and Wenshui, 2005), stimulate immune response or have physiological effects on the body. Food products containing "bioactive" components, sometimes termed functional foods, are increasingly sought by consumers. The type of feed ingested by ruminants has a considerable effect on milk composition, and proper diets enable the content of vitamins, $\beta$-carotene and essential fatty acids to be modified (Dhiman et al., 2000; White et al., 2001; Nozière et al., 2006). Reducing the proportion of concentrates and increasing the proportion of roughages will often result in lower yield but higher biological value of the milk. Research demonstrates that milk obtained from pasture-fed cows contains more vitamins A and E (Reklewska et al., 2003; Leiber et al., 2005; Nozière et al., 2006), $\beta$-lactoglobulin and lactoferrin (Reklewska and Reklewski, 2004; Król et al., 2008) and CLA (Dhiman et al., 2000; Auldist et al., 2002; Loor et al., 2003; Elgersma et al., 2004). The feeding system of cows has a considerable impact on the quality of their milk and dairy products. According to Radkowska and Herbut (2017), pasture feeding of Simmental cows has a positive effect on the processing suitability of milk and the sensory attributes of produced rennet cheese and butter.

Therefore, the aim of the present study was to determine the yield and nutrient content of milk from Simmental cows fed TMR diets vs. those kept on pasture.

\section{Material and methods}

The experiment was conducted with Simmental dairy cows in their second and third lactation (between 30 and 200 days of milking). Animals were assigned to two groups: cows housed indoors and fed TMR diets (group I) and cows kept on pasture (group II). The observations were made from 10 May to 15 October. Cows from group I were fed a TMR which contained maize silage $-25 \mathrm{~kg}$, haylage $-8 \mathrm{~kg}$, fresh brewers grains $-8 \mathrm{~kg}$, ensiled maize grain $-4.5 \mathrm{~kg}$, rapeseed cake $-2 \mathrm{~kg}$, extracted soybean meal $(48 \% \mathrm{CP})-1.2 \mathrm{~kg}$, meadow hay $-0.5 \mathrm{~kg}$, straw $-0.5 \mathrm{~kg}$, and mineral supplements. The nutritive value of the TMR per $\mathrm{kg}$ of $\mathrm{d} . \mathrm{m}$. was $0.86 \mathrm{UFL}, 0.86$ LFU, $91 \mathrm{~g}$ PDIE, and $100 \mathrm{~g}$ PDIN.

Cows from group II were kept day and night on pasture, spending time in the barn twice daily; once from 5:00 a.m. to 7:00 a.m. and again from 2-3:00 p.m. (depending 
on the temperature) to 5:00 p.m., when the cows were milked and fed supplementary concentrate. The cows consumed from 45 to $55 \mathrm{~kg}$ of forage/day and were supplemented with $1 \mathrm{~kg}$ of concentrate per 2 litres of milk above 15 litres milk yield. Strip grazing management was used. During the vegetative period, the botanical composition of the sward was assessed before each grazing. The pasture was dominated by grasses, which formed almost $80 \%$, including perennial ryegrass (Lolium perenne L.), red fescue (Festuca rubra L.), and smooth-stalked meadow-grass (Poa pratensis L.). The proportion of legumes and dicotyledons averaged $11 \%$ and $9 \%$, respectively. The nutritive value of pasture sward was $1.02 \mathrm{UFL}, 0.93 \mathrm{LFU}, 108 \mathrm{~g}$ PDIE, and $139 \mathrm{~g}$ PDIN.

There were approximately 50 cows in each experimental group. The cows' milk yield was determined for the entire technological group, and 10 cows were selected from each group for detailed analysis. The bioactive components were determined in milk samples in which the somatic cell count was $<400000 \cdot \mathrm{ml}^{-1}$.

Vitamins A and E were determined according to SOP M.001 methodology ver. 6 of 19 March 2012 "Simultaneous determination of vitamins A and E in solid or bulk materials - test-tube method". Higher fatty acids were analysed by gas chromatography (P 015-1 ver. 2 of 1 March 2016. Catalog: III kw 2016/209_15.xls), column: Rtx$2330,105 \mathrm{~m}, 0.32 \mathrm{~mm}, 0.2 \mathrm{micron}$. Program temp. $60^{\circ} \mathrm{C}$ for $10 \mathrm{~min} ; 20^{\circ} \mathrm{C} \cdot \mathrm{min}^{-1}$ to $120^{\circ} \mathrm{C} ; 3^{\circ} \mathrm{C} \cdot \mathrm{min}^{-1}$ to $240^{\circ} \mathrm{C}$. Time of analysis: $60 \mathrm{~min}$, injector temp.: $250^{\circ} \mathrm{C}$, detector temp.: $250^{\circ} \mathrm{C}$, carrier gas: helium, $3 \mathrm{ml} / \mathrm{min}$, injection volume: $1.0 \mathrm{mcl}$. Cholesterol content was determined according to SOP M.023a ver. 1 of 20 October 2011 "GC determination of cholesterol in meat and milk". Calcium, magnesium, sodium and potassium were determined by flame atomic absorption spectrometry (SOP M.008c - accredited method), and phosphorus content according to SOP M.009 - accredited method of "Spectrophotometric determination of phosphorus in feeds, meat, bones, feces, eyes, milk and milk products". Selenium content was determined according to "Determination of selenium content in products of plant and animal origin. Hydride generation atomic absorption spectrometry method. P017 ann. 2 ver. 2 of 9 February 2008 - non-accredited method"; iodine content according to the "Catalytic colorimetric method after the mineralization in ammonium persulfate. SOP M.016d ver. 1 of 22 April 2010 - accredited method". These analyses were performed at the Central Laboratory of the National Research Institute of Animal Production in Aleksandrowice. The content of milk protein fractions was determined at the Department of Animal Product Technology of the University of Agriculture in Kraków. Protein fractions were separated by SDS PAGE gel electrophoresis.

The differences between group means were examined by ANOVA and Duncan's test using Statistica 12 (StatSoft, Poland, 2013).

\section{Results}

The results for milk yield and chemical composition of the milk are presented in Table 1. In group II (pasture feeding with supplemental concentrate), the milk 
yield was observed to increase considerably during the spring and summer months (Figure 1). The highest daily milk yield of $23.8 \mathrm{~kg}$ was observed in group II in May and June. The analysis of protein fractions in the studied milk showed that the milk from group II cows contained significantly more $\beta$-casein, $\beta$-lactoglobulin, $\alpha$-lactalbumin and peptides. It also had a non-significantly higher lactoferrin content. The milk of TMR-fed cows from group I contained more $\alpha$-casein and $\kappa$-casein. The milk of cows grazed on pasture (group II) contained $0.067 \mu \cdot \mathrm{g}^{-1}$ more vitamin A and $0.22 \mu \cdot \mathrm{g}^{-1}$ more vitamin E (Table 1). This milk also contained significantly $(\mathrm{P} \leq 0.05)$ less saturated fatty acids (SFA), and more $(\mathrm{P} \leq 0.05)$ mono- (MUFA) and polyunsaturated fatty acids (PUFA), as a result of which the MUFA:SFA and PUFA:SFA ratios in this group were more beneficial at 0.448 and 0.066 , respectively (Table 2). Also the content of hypocholesterolemic desirable fatty acids (DFA) was higher in group II, and the DFA:OFA ratio was 0.8. Compared to the milk of TMR-fed cows, the milk of grazed cows had more than twice as much CLA ( $1.59 \%$ of all acids) and $35 \%$ more $n$ - 3 PUFA, which resulted in a more favourable $n-6 / n-3$ fatty acids ratio of 2.88 . The present analysis showed significant $(\mathrm{P} \leq 0.05)$ differences in the milk cholesterol content (Figure 2), which was 0.096 $\mathrm{mg} \cdot \mathrm{g}^{-1}$ in the milk of cows from group I compared to $0.078 \mathrm{mg} \cdot \mathrm{g}^{-1}$ in the milk of cows from group II. Determinations of the content of macro- and microelements showed a significantly higher concentration of magnesium and iodine in the milk of cows from group II (Table 3). This milk also had a non-significantly higher calcium and phosphorus content. The milk of TMR-fed cows contained more sodium and selenium.

Table 1. Yield, protein fractions and vitamins content of milk

\begin{tabular}{lccc}
\hline \multicolumn{1}{c|}{ Item } & Group I & Group II & SEM \\
\hline Yield $(\mathrm{kg})$ & $20.63 \mathrm{a}$ & $23.21 \mathrm{~b}$ & 0.22 \\
Composition of milk protein fractions $(\%$ of total proteins) & & & \\
Protein fraction: & & & \\
$\quad \alpha$-casein & $35.58 \mathrm{~b}$ & $33.55 \mathrm{a}$ & 0.47 \\
$\beta$-casein & $20.22 \mathrm{a}$ & $22.02 \mathrm{~b}$ & 0.29 \\
K-casein & $14.64 \mathrm{~b}$ & $13.77 \mathrm{a}$ & 0.38 \\
$\beta$-lactoglobulin & $14.30 \mathrm{a}$ & $15.13 \mathrm{~b}$ & 0.42 \\
$\alpha$-lactalbumin & $7.80 \mathrm{a}$ & $8.46 \mathrm{~b}$ & 0.12 \\
immunoglobulins & $1.63 \mathrm{~b}$ & $1.27 \mathrm{a}$ & 0.06 \\
serum albumin & $1.87 \mathrm{~b}$ & $1.57 \mathrm{a}$ & 0.08 \\
lactoferrin & 0.92 & 0.95 & 0.03 \\
peptides & $3.04 \mathrm{a}$ & $3.79 \mathrm{~b}$ & 0.18 \\
Vitamins content of milk $\left(\mu \mathrm{g} \cdot \mathrm{g}^{-1}\right)$ & & & 0.02 \\
vitamin A & $0.333 \mathrm{a}$ & $0.400 \mathrm{~b}$ & 0.11 \\
vitamin E & $0.782 \mathrm{a}$ & $1.002 \mathrm{~b}$ & 0.11 \\
\hline
\end{tabular}

$\mathrm{a}, \mathrm{b}-$ significant differences $(\mathrm{P} \leq 0.05)$. 


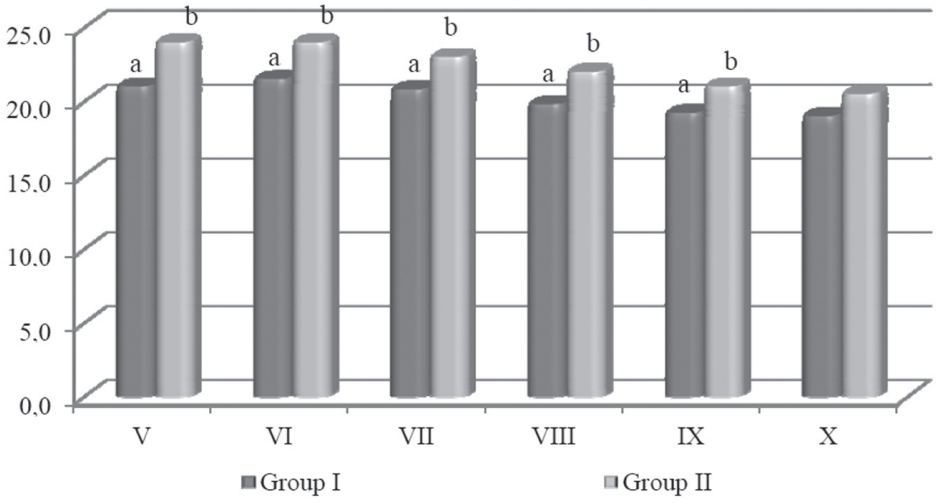

$a, b-$ significant differences $(\mathrm{P} \leq 0.05)$.

Figure 1 . Mean daily milk yield $(\mathrm{kg})$ by month

Table 2. Fatty acids content of milk (g per $100 \mathrm{~g}$ of all fatty acids)

\begin{tabular}{lcccc}
\hline & Fatty acid & Group I & Group II & SEM \\
\hline & 1 & 2 & 3 & 4 \\
\hline C8:0 & $2.279 \mathrm{~b}$ & $1.986 \mathrm{a}$ & 0.069 \\
C10:0 & $4.289 \mathrm{~b}$ & $3.382 \mathrm{a}$ & 0.199 \\
C12:0 & $5.183 \mathrm{~b}$ & $4.059 \mathrm{a}$ & 0.237 \\
C14:0 & $15.471 \mathrm{~b}$ & $14.478 \mathrm{a}$ & 0.397 \\
C16:0 & 32.515 & 31.661 & 0.714 \\
C16:1 & $1.407 \mathrm{a}$ & $1.549 \mathrm{~b}$ & 0.044 \\
C18:0 & 10.700 & 10.592 & 0.357 \\
C18:1 & $24.418 \mathrm{a}$ & $27.795 \mathrm{~b}$ & 1.090 \\
C18:2 & $1.805 \mathrm{~b}$ & $1.605 \mathrm{a}$ & 0.121 \\
gamma18:3 & 0.171 & 0.165 & 0.046 \\
C18:3 & $0.441 \mathrm{a}$ & $0.605 \mathrm{~b}$ & 0.047 \\
CLAc9-t11 & $0.680 \mathrm{a}$ & $1.470 \mathrm{~b}$ & 0.189 \\
CLAt10-c12 & 0.002 & 0.002 & 0.000 \\
CLAc9-c11 & $0.015 \mathrm{a}$ & $0.077 \mathrm{~b}$ & 0.035 \\
CLAt9-t11 & $0.027 \mathrm{a}$ & $0.042 \mathrm{~b}$ & 0.003 \\
C20:0 & $0.094 \mathrm{~b}$ & $0.085 \mathrm{a}$ & 0.027 \\
C20:4 & $0.358 \mathrm{~b}$ & $0.287 \mathrm{a}$ & 0.004 \\
C22:0 & $0.048 \mathrm{~b}$ & $0.038 \mathrm{a}$ & 0.027 \\
C22:1 & $0.016 \mathrm{~b}$ & $0.013 \mathrm{a}$ & 0.001 \\
EPA & $0.078 \mathrm{a}$ & $0.105 \mathrm{~b}$ & 0.011 \\
DHA & 0.006 & 0.005 & 0.001 \\
SFA & $70.576 \mathrm{~b}$ & $66.282 \mathrm{a}$ & 1.207 \\
UFA & $29.424 \mathrm{a}$ & $33.718 \mathrm{~b}$ & 1.207 \\
MUFA & $25.841 \mathrm{a}$ & $29.357 \mathrm{~b}$ & 1.126 \\
\hline & & &
\end{tabular}


Table 2 - contd.

\begin{tabular}{l|c|c|c}
\hline & 2 & 3 & 4 \\
\hline PUFA & $3.583 \mathrm{a}$ & $4.363 \mathrm{~b}$ & 0.209 \\
PUFA-6 & $2.335 \mathrm{~b}$ & $2.057 \mathrm{a}$ & 0.179 \\
PUFA-3 & $0.526 \mathrm{a}$ & $0.715 \mathrm{~b}$ & 0.055 \\
DFA & $40.124 \mathrm{a}$ & $44.309 \mathrm{~b}$ & 1.383 \\
OFA & $59.873 \mathrm{~b}$ & $55.690 \mathrm{a}$ & 1.986 \\
UFA:SFA & $0.418 \mathrm{a}$ & $0.513 \mathrm{~b}$ & 0.028 \\
DFA:OFA & $0.672 \mathrm{a}$ & $0.808 \mathrm{~b}$ & 0.072 \\
MUFA:SFA & $0.367 \mathrm{a}$ & $0.448 \mathrm{~b}$ & 0.026 \\
PUFA:SFA & $0.052 \mathrm{a}$ & $0.066 \mathrm{~b}$ & 0.004 \\
PUFA 6/3 & $4.628 \mathrm{~b}$ & $2.888 \mathrm{a}$ & 0.306 \\
CLA & $0.724 \mathrm{a}$ & $1.591 \mathrm{~b}$ & 0.213 \\
\hline
\end{tabular}

$\mathrm{a}, \mathrm{b}$ - significant differences $(\mathrm{P} \leq 0.05)$.

\section{Cholesterol $\left(\mathrm{mg} \cdot \mathrm{g}^{-1}\right)$}

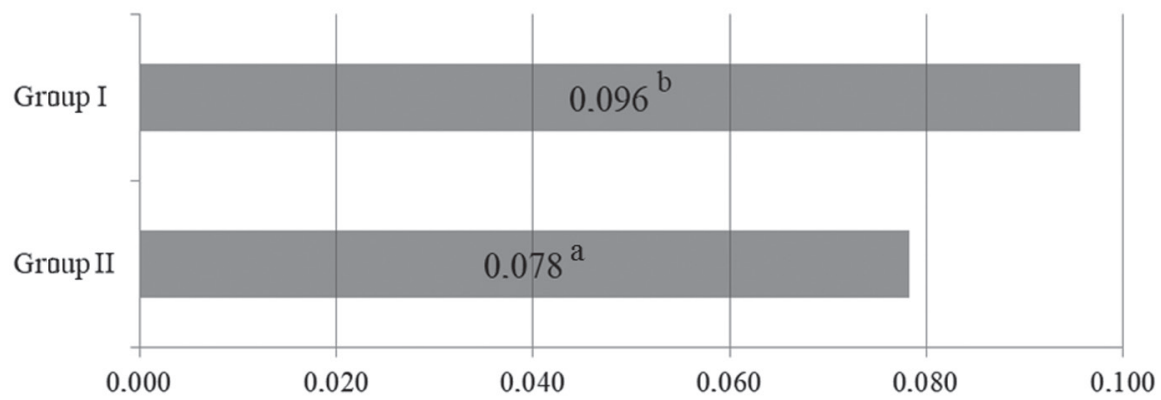

Figure 2. Cholesterol content in milk $\left(\mathrm{mg} \cdot \mathrm{g}^{-1}\right)$

Table 3. Content of macro- and microelements in milk

\begin{tabular}{lllll}
\hline \multicolumn{1}{c|}{ Parameter } & Group I & Group II & SEM \\
\hline $\mathrm{Ca}\left(\mathrm{g}^{\mathrm{kg}} \mathrm{kg}^{-1}\right)$ & 1.18 & 1.22 & 0.021 \\
$\mathrm{Mg}\left(\mathrm{g} \cdot \mathrm{kg}^{-1}\right)$ & $0.094 \mathrm{a}$ & $0.106 \mathrm{~b}$ & 0.003 \\
$\mathrm{P}\left(\mathrm{g} \cdot \mathrm{kg}^{-1}\right)$ & 0.96 & 0.98 & 0.021 \\
$\mathrm{Na}\left(\mathrm{g} \cdot \mathrm{kg}^{-1}\right)$ & 0.37 & 0.35 & 0.015 \\
$\mathrm{Se}\left(\mathrm{mg}^{-1} \mathrm{~kg}^{-1}\right)$ & $0.016 \mathrm{~b}$ & $0.014 \mathrm{a}$ & 0.001 \\
$\mathrm{I}\left(\mu \mathrm{g} \cdot \mathrm{g}^{-1}\right)$ & $0.178 \mathrm{a}$ & $0.196 \mathrm{~b}$ & 0.029 \\
\hline
\end{tabular}

$\mathrm{a}, \mathrm{b}$ - significant differences $(\mathrm{P} \leq 0.05)$. 


\section{Discussion}

Feeding is one of the major factors that determines the yield, chemical composition, and nutritive value of cow's milk (White et al., 2001). High feeding intensity increases milk yield but at the same time reduces milk quality. In the conventional feeding system, seasonal variation in the quality of ingested feed is the main decisive factor for milk yield. The results of research concerning the yield and composition of milk with regard to feeding system are inconclusive. Many studies demonstrate that compared to conventional feeding, cows fed total mixed rations produce more milk (White et al., 2001; Król et al., 2008; Barłowska et al., 2012). White et al. (2001) found higher milk yield in TMR- compared to pasture-fed Holstein cows, however pasture-fed Jersey cows showed higher milk yield. Pasture as the sole source of feed is insufficient for high-yielding cows. Lower intake of dry matter and energy results in lower production, even when pasture quantity and quality is appropriate (Bargo et al., 2002); therefore, to make the rations balanced, it is recommended to feed cows with concentrates as well as feeds containing NDF and ADF. The present study shows that with proper supplementation, it is possible to obtain higher milk yield during the summer period in Simmental cows fed on pasture compared to those fed TMR. Proper combination of high-protein forages with high-energy feeds (e.g. maize silage) is essential. Kuczyńska et al. (2011) obtained a yield of $24.6 \mathrm{~kg}$ milk/animal/day from cows that were fed in the summer season with pasture forage, wilted grass haylage and concentrate that formed $19.6 \%$ of the ration's dry matter. Likewise, Auldist et al. (2014) reported that proper supplementation may considerably increase the production of milk in pasture-fed cows.

Research shows that whey proteins are an important group of biologically active compounds with antioxidant, immune-activating, antibacterial, antiviral and anticancerous properties. The main whey protein in cow's milk is $\beta$-lactoglobulin, which plays a significant antioxidant role in milk (Ness-Abramof et al., 2006). Mackle et al. (1999) showed that the level of $\alpha$-LA and $\beta$-LG decreases when cows have limited access to pasture. Research shows that milk from conventionally fed cows contains many more functional whey proteins, and these differences are considerably greater during the summer season (Barłowska et al., 2012). Similar results were obtained by Reklewska and Reklewski (2004) as well as Król et al. (2008), who observed the content of $\alpha$-lactalbumin, $\beta$-lactoglobulin and lactoferrin to be much higher in milk from grazed cows compared to those receiving conserved feeds. In the study by Król et al. (2008), the concentrations of $\alpha$-LA, $\beta$-LG and lactoferrin in the milk from grazed cows were significantly higher than in the milk from TMR-fed cows $\left(1.14 \mathrm{~g} \cdot \mathrm{l}^{-1}\right.$ vs. $1.0 \mathrm{~g} \cdot \mathrm{l}^{-1} ; 3.7 \mathrm{~g} \cdot \mathrm{l}^{-1}$ vs. $3.17 \mathrm{~g} \cdot \mathrm{l}^{-1} ; 116.2 \mathrm{mg} \cdot \mathrm{l}^{-1}$ vs. $\left.88.3 \mathrm{mg} \cdot \mathrm{l}^{-1}\right)$. Likewise, Kuczyńska et al. (2012) reported that the milk from organically farmed cows con-

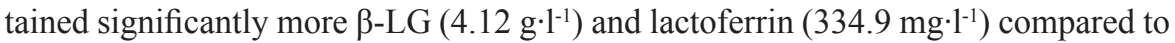
the milk from conventionally raised cows $\left(2.68 \mathrm{~g} \cdot \mathrm{l}^{-1} \beta-\mathrm{LG}, 188.0 \mathrm{mg} \cdot \mathrm{l}^{-1}\right.$ lactoferrin). Zagorska (2007) demonstrated that in the milk from organically raised cows, Lf is almost twice as high as in the milk from TMR-fed cows. Research shows that the level of $\beta$-LG is associated with the vitamin A content of cow's milk. Kuczyńska et al. (2011) found the highest level of this whey protein $\left(3.87 \mathrm{~g} \cdot \mathrm{l}^{-1}\right)$ in a farm where 
cows are fed on pasture with supplemental silage as well as concentrate during the summer, and at the same time showed the highest concentration of vitamin A during the same period. Dolores-Perez and Calvo (1994) provided evidence that the concentration of both components is correlated, because $\beta$-LG takes an active part in the transport of retinol with a significant contribution to its level. Coulon et al. (1998) found that milk casein content is dependent more on genetic than nutritional factors. This is also confirmed by Walker et al. (2004) and our study. In turn, Auldist et al. (2000) reported that pasture feeding is conducive to increasing the content of casein proteins in cow's milk.

Milk is a major source of fat-soluble vitamins, notably vitamins $\mathrm{A}$ and $\mathrm{E}$. The higher $(\mathrm{P} \leq 0.05)$ concentration of vitamins $\mathrm{A}$ and $\mathrm{E}$ in the milk of pasture-fed cows from group II, found in our study, corresponds with the findings of other authors (Leiber et al., 2005; Nozière et al., 2006). Reklewska et al. (2003) demonstrated that the milk from cows grazed on pasture contains more vitamins than the milk from TMR-fed cows $\left(0.32\right.$ vs. $\left.0.26 \mathrm{mg}^{-1} \mathrm{l}^{-1}\right)$. Fresh pasture sward has a higher content of vitamin E and provitamin A compared to conserved feeds (Nozière et al., 2006), and therefore the content of these vitamins in milk is observed to increase during the summer feeding season in organic farms or in farms where cows are fed pasture. In turn, a high proportion of silage in the ration may reduce the concentration of these vitamins in milk (Nozière et al., 2006). Observations made in Switzerland showed that the milk from cows fed only grass contains almost $90 \%$ more alpha-tocopherol compared to the milk from cows fed a silage- and concentrate-based diet. An even higher concentration of alpha-tocopherol (by more than 130\%) was found in the milk from cows grazed on alpine pastures (Leiber et al., 2005).

The factor most significantly influencing CLA content in milk fat is nutrition (type of diet, supplements affecting ruminal fibre fermentation, fat additives), whereas genetic factors (breed) and physiological factors (stage of lactation, age) have a smaller effect (Kelsey et al., 2003). Research results show that the milk from pasture-grazed cows, compared to TMR-fed cows, is characterized by higher CLA concentration (Dhiman et al., 2000; White et al., 2001). Dhiman et al. (2000) reported that cows grazed on pasture had a three-fold higher content of CLA in milk fat ( $2.21 \%$ of total fatty acids) compared to cows fed a diet containing $50 \%$ conserved feeds (hay, silage) and $50 \%$ grain $(0.38 \%$ of total fatty acids). In the study by Elgersma et al. (2004) CLA content was $2.30 \%$ during the pasture feeding period, but after introducing a diet comprised of grass and maize silage it gradually decreased to $0.95 \%$ on day 2 , to $0.43 \%$ on day 6 , and to $0.37 \%$ on day 14 after the change of diet. Increased CLA content in the milk of pastured cows compared to TMR-fed cows was also reported by Auldist et al. (2002) and Loor et al. (2003). The results of our study confirm the beneficial effect of pasture feeding on the CLA content of milk. This milk contained less saturated fatty acids (SFA) and more mono- (MUFA) and polyunsaturated fatty acids (PUFA). As in our study, Whiting et al. (2004) obtained a more beneficial UFA:SFA ratio in summer $(0.47-0.58 \%)$ than in winter $(0.32-0.37 \%)$. Seasonal increases in the proportion of unsaturated fatty acids (UFA) in milk during the summer (pasture) feeding season as well as in the omega-3 to omega- 6 fatty acids ratio were also reported by Frelich et al. (2012). The results 
showed that milk obtained during the summer period had a more desirable composition for human health compared to the milk collected in winter, and therefore this milk may be welcomed by consumers.

Milk cholesterol concentration is determined by genetic factors as well as environmental factors, mainly the diet (Strzałkowska et al., 2009). However, the cholesterol content is not easy to control. Factors that reduce LDL cholesterol in the blood of animals do not always reduce this component in milk. Reklewska et al. (2002) demonstrated that linseed added to the cow ration decreased the milk cholesterol content by $32 \%$ compared to the control group. The lower cholesterol concentration noted in the milk from group II cows corresponds with the results of White et al. (2001) and Barłowska et al. (2011). In the latter study, milk from TMR-fed cows contained more cholesterol (by around $2.18 \mathrm{mg} \cdot 100^{-1} \mathrm{ml} \mathrm{milk}$ ) compared to the milk from conventionally fed cows.

The effect of pasture feeding on the mineral composition of milk is inconclusive. Król et al. (2010) found the milk from conventionally farmed cows to contain more $\mathrm{Ca}$ (by an average of $125.2 \mathrm{mg} \cdot \mathrm{dm}^{3}$ ) and $\mathrm{Mg}$ (by an average of $22.4 \mathrm{mg} \cdot \mathrm{dm}^{3}$ ) compared to milk produced by intensive methods. In turn, Gabryszuk et al. (2008), who compared the $\mathrm{Ca}, \mathrm{P}$ and $\mathrm{Mg}$ content of milk obtained in intensive production system (without grazing) to that from milk produced by extensive farms (that apply grazing), found the level of these elements to be considerably higher in the milk obtained under the intensive system. The mineral content of milk is mainly determined by the mineral content of the feed, which, in turn, depends on local soil and climate conditions as well as the extent to which mineral supplements are used. The disparity in the research results may arise from the fact that mineral and vitamin supplements are used in high-yielding herds.

The main source of selenium for dairy cows are plants in which selenium is easily assimilable. However, selenium content in plants varies according to plant species and the abundance of selenium in the soil in which the plants are grown. The study by Brzóska et al. (2003) showed that plants cultivated in Poland are characterized by a particularly low content of selenium, which is less than $60 \%$ of the content presented in feed composition tables. Ceballos-Marquez et al. (2010) reported that during the pasture feeding period, $14 \%$ of cows in the herd had very low selenium concentrations in milk, which is due to the shortage of this element in feed. These results agree with the results of the present study, in which lower selenium concentration was found in the pastured group (group II).

Iodine content in milk and in other milk products varies considerably and is associated with environmental iodine content as well as seasons of the year (Fiedlerová, 1998). A Czech study showed milk iodine content to range from 24 to $748 \mu \mathrm{g} \cdot \mathrm{kg}^{-1}$ (205 $\mu \mathrm{g} \cdot \mathrm{kg}^{-1}$ on average) in winter and from 16 to $345 \mu \mathrm{g} \cdot \mathrm{kg}^{-1}\left(119 \mu \mathrm{g} \cdot \mathrm{kg}^{-1}\right.$ on average) in summer (Fiedlerová, 1998). Iodine content in cow's milk depends on the amount of dietary iodine intake. The relationship between iodine content in feed ration and in milk is expressed by the correlation coefficient 0.66 (Maas et al., 1989). The iodine content of roughages varies during the vegetative season. A study conducted in south-western Czech Republic demonstrated that iodine content in pasture sward averaged 101.3 \pm 73.6 from May to July, and 214.5 $\pm 107.3 \mu \mathrm{g} \mathrm{I} \cdot \mathrm{l}^{-1}$ from Au- 
gust to October (Trávníček et al., 2004). A study performed in Poland in 2011-2012 (Śliwiński et al., 2015), which monitored iodine content in consumer milk, showed that it contained from 103 to $196 \mu \mathrm{g}$ iodine $\mathrm{kg}^{-1}$ in the summer season, and from 141 to $236 \mu \mathrm{g}$ iodine $\cdot \mathrm{kg}^{-1}$ in the winter season. Thus, our results for milk iodine content (178 $\mu \mathrm{g} \cdot \mathrm{kg}^{-1}$ - group I and $196 \mu \mathrm{g} \cdot \mathrm{kg}^{-1}$ - group II) allow this milk to be classified as having optimum iodine content.

It is concluded from the present study that compared to TMR feeding, the use of summer pasture feeding and a proper supplemented feeding ration in Simmental cows with high-energy feeds allow for higher milk yield and higher nutritive value of the milk. In farms with sufficient pasture area, it is appropriate to use grazing in the summer period. This allows breeders to feed cows with cheap feed such as pasture sward and thus to considerably reduce the costs incurred on feeding while achieving high milk yields and high concentration of bioactive components in the milk.

\section{References}

A uld is t M.J., Thom son N.A., M a ckle T.R., Hill J.P., Pros ser C.G. (2000). Effects of pasture allowance on the yield and composition of milk from cows of different $\beta$-lactoglobulin phenotypes. J. Dairy Sci., 83: 2069-2074.

A u ld is t M.J., K a y J.K., Th o m s on N.A., N a p per A.R., Kolve r E.S. (2002). Concentration of conjugated linoleic acid in milk from cows grazing pasture or fed a total mixed ration for an entire lactation. Brief communication. Proc. of the New Zealand Society of Animal Production, 62: 240-241.

A uldist M.J., Marett L.C., Gree nwo od J.S., Wright M.M., Hannah M., Jac obs J.L., Wa le s W.J. (2014). Replacing wheat with canola meal in a partial mixed ration increases the milk production of cows grazing at a restricted pasture allowance in spring. Anim. Prod. Sci., 54: 869-878.

B arg o F., Mulle r L.D., D e lah o y J.E., C a s s idy T.W. (2002). Performance of high producing dairy cows with three different feeding systems combining pasture and total mixed rations. J. Dairy Sci., 85: 2948-2963.

Barłowska J., Szwajkowska M., Litwińczuk Z., Matwijczuk A. (2011). The influence of cow breed and feeding system on the dispersion state of milk fat and content of cholesterol. (In Polish). Sci. Ann. Polish Soc. Anim. Prod., 7: 57-65.

B arłowska J., Litwiń c zuk Z., B rodziak A., Chabuz W. (2012). Effect of the production season on nutritional value and technological suitability of milk obtained from intensive (TMR) and traditional feeding system of cows. J. Microbiol. Biotechn. Food Sci., 1: 1205-1220.

Brzóska F., B rzeziński W., Brzósk a B. (2003). Mineral nutrients in Polish feedstuffs. Part 1. Fodder plants. Ann. Anim. Sci., 3: 115-126.

Ceballos-Marquez A., B arkema H.W., Stryhn H., Dohoo I.R., Ke efe G.P., Wicht e 1 J.J. (2010). Milk selenium concentration and its association with udder health in Atlantic Canadian dairy herds. J. Dairy Sci., 93: 4700-4709.

Coulon J.B., Hurt a u C., Re mond B., Verit e R. (1998). Factors contributing to variation in the proportion of casein in cows' milk true protein: A review of recent INRA experiments. J. Dairy Res., 65: 375-387.

D h i man T.R., S a t t e r L.D., P a triza M.W., Galli M.P., A 1 bright K., To 1 o s a M.X. (2000). Conjugated linoleic acid (CLA) content of milk from cows offered diets rich in linoleic and linolenic acid. J. Dairy Sci., 83: 1016-1027.

Dolores-Perez M., Calvo M. (1994). Interaction of beta-lactoglobulin with retinol and fatty acids and its role as a possible biological function for this protein: Review. J. Dairy Sci., 78: 978-988. 
Elgersma A., Ellen G., Van der Horst H., Boer H., Dekker P.R., Tamminga S. (2004). Quick changes in milk fat composition after transition from fresh grass to a silage diet. Anim. Feed Sci. Technol., 117: 13-27.

F i e d l e r ová V. (1998). Spectrophotometric determination of iodine and its content and stability in selected food raw materials and products. Czech J. Food Sci., 16: 163-167.

Frelich J., Sla chta M., Hanus O., S picka J., S a mkova E., We glarz A., Zapletal P. (2012). Seasonal variation in fatty acid composition of cow milk in relation to the feeding system. Anim. Sci. Pap. Rep., 30: 219-229.

Gabryszuk M., Słon i ew ski K., S a k ow s ki T. (2008). Macro- and microelements in milk and hair of cows from conventional vs. organic farms. Anim. Sci. Pap. Rep., 26: 199-209.

Kels e y J.A., Corl B.A., Colli e r R.J., B a uman D.E. (2003). The effect of breed, parity and stage of lactation on conjugated linoleic acid (CLA) in milk fat from dairy cows. J. Dairy Sci., 86: $2588-2597$.

Król J., Litwińczuk Z., Litwińczuk A., Brodziak A. (2008). Content of protein and its fractions in milk of Simmental cows with regard to rearing technology. Ann. Anim. Sci., 1: 57-61.

Kró 1 J., Brodzi a k A., Wola n c i u k A., W ój cik M. (2010). Elements' content in milk of Simmental cows depending on feeding system. (In Polish). Sci. Ann. Polish Soc. Anim. Prod., 6: 321328.

Kuczyńska B., Nałęcz-Tarwacka T., Puppel K., Gołębiewski M., Grodzki H., S ló s a r z J. (2011). The content of bioactive components in milk depending on cow feeding model in certified ecological farms. J. Res. Applic. Agric Eng., 56: 7-13.

Kuczyńska B., Puppel K., Gołębiewski M., Metera E., Sakowski T., Słoniews k i K. (2012). Differences in whey protein content between cow's milk collected in late pasture and early indoor feeding season from conventional and organic farms in Poland. J. Sci. Food Agric., 92: $1-6$.

Le iber F., Kreuzer M., N igg D., Wet t s t e in H.R., S c he e d e r M.R. (2005). A study on the causes for the elevated n-3 fatty acids in cows' milk of alpine origin. Lipids, 40: 191-202.

L o or J.J., S oriano F.D., Li n X., H e rbe in J.H., P ol an C.E. (2003). Grazing allowance after the morning or afternoon milking for lactating cows fed a total mixed ration (TMR) enhances trans-11 - 18:1 and cis-9, trans-11 - 18:2 (rumenic acid) in milk fat to different extents. Anim. Feed Sci. Technol., 103: 105-119.

M a a s J., B erg J.N., P e ter s e n R.G. (1989). Serum distribution of iodine after oral administration of ethylenediamine dihydroiodide in cattle. American J. Veter. Res., 50: 1758-1759.

Mackle T.R., B ryant A.M., P e t ch S.F., H o o per R.J., A u ld is t M.J. (1999). Variation in the composition of milk protein from pasture-fed dairy cows in late lactation and the effect of grain and silage supplementation. New Zealand J. Agric. Res., 42: 147-154.

Nes s - A bram of R., N abris ki D.A., Braverman L.E., Shilo L., We is s E., Res hef T., $\mathrm{S}$ h a p iro M.S., S h e $\mathrm{k}$ m a n L. (2006). Prevalence and evaluation of B12 deficiency in patients with autoimmune thyroid disease. American J. Med. Sci., 332: 119-122.

Nozi èr e P., Gra u l e t B., L u c a s A., M a r t in P., Groli er P., D or e a u M. (2006). Carotenoids for ruminants: From forages to dairy products. Anim. Feed Sci. Technol., 131: 418-450.

R a d k ow s k a I., H e r b u t E. (2017). The effect of housing system of Simmental cows on processing suitability of milk and quality of dairy products. Anim. Sci. Pap. Rep., 35: 147-158.

Reklewska B., Reklewski Z. (2004). Potential for producing milk with elevated content of functional components. Anim. Sci. Pap. Rep., 22: 367-374.

Reklewska B., Oprządek A., Reklewski Z., Panicke L., Kuczyńska B., Oprzą d e k J. (2002). Alternative for modifying the fatty acid composition and decreasing the cholesterol level in the milk of cows. Livest. Prod. Sci., 76: 235-243.

Reklewska B., Bernatowicz E., Reklewski Z., Nałęcz-Tarwacka T., Kuczyńs k a B., Z dzi arski K., O prząd e k A. (2003). Concentration of milk functional components in Black-and-White cows, depending on the season and feeding system. (In Polish). Zesz. Nauk. Prz. Hod., 68: 85-98.

S e verin S., We n s h u i X. (2005). Milk biologically active components as nutraceuticals. Crit. Rev. Food Sci., 45: 645-656. 
Strzałkowska N., Jóźwik A., Bagnicka E., Krzyżewski J., Horbańczuk J.O. (2009). Studies upon genetic and environmental factors affecting the cholesterol content of cow milk. II. Effect of silage type offered. Anim. Sci. Pap. Rep., 27: 199-206.

Śliwiński B., Brzóska F., Szybiński Z. (2015). Iodine concentration in Polish consumer milk. Ann. Anim. Sci., 15: 799-810.

Travn ič e k J., K r o u p o v a V., S o c h M. (2004). Iodine content in bulk feeds in western and southern Bohemia. Czech J. Anim. Sci., 49: 483-484.

Walker G.P., Dunshea F.R., Doyle P.T. (2004). Effects of nutrition and management on the production and composition of milk fat and protein. A review. Aust. J. Agric. Res., 55: 1009-1028.

White S.L., Bertrand J.A., Wade M.R., Washburn S.P., Green J.T.J., Jenkins T.C. (2001). Comparison of fatty acid content of milk from Jersey and Holstein cows consuming pasture or a total mixed ration. J. Dairy Sci. 84: 2295-2301.

Whiting C.M., Muts vangwa T., Wal to n J.P., Cant J.P., M c bride B.W. (2004). Effects of feeding either fresh alfalfa or alfalfa silage on milk fatty acids content in Holstein dairy cows. Anim. Feed Sci. Technol., 113: 27-37.

$\mathrm{Z}$ a g o r s k a J. (2007). The evaluation of organic milk quality. Summary of doctoral thesis. Latvia Univ. Agric. Jelgava., pp. 1-63.

Received: 19 III 2018

Accepted: 11 VI 2018 